\title{
A Contribution to the Debate on Reconciling Bioenergy for Biofuels and Food Security
}

\author{
Paulo C. Manduca, Mauro D. Berni, Rubens Lamparelli, Klaus G. Dalgaard, Luis A. B. Cortez, and \\ Juan A. Ayarza
}

\begin{abstract}
Over the last few years, bioenergy production has undergone a process of rapid development, causing significant impacts on the global food system. Among other things, the resulting increase in demand for agricultural products has had important implications for food security. The alleged causal link between bioenergy production and food security has been the subject of increasing debate. Given the complex nature of bioenergy, debates on the matter often lack a solid scientific basis. The endurance of such debates raises the need for more informed and systematic attention to this issue. The present paper identifies some of the main players in this debate and their arguments in favor or against the expansion of biofuel industries. A case study of the Brazilian experience with biofuels will clarify the validity of arguments on both sides of the debate and the potential applicability of the Brazilian biofuel model worldwide.
\end{abstract}

Index Terms-Bioenergy, biofuels, food security, sustainability.

\section{INTRODUCTION}

Bioenergy is growing as an alternative energy source with low levels of greenhouse gas (GHG) emissions. However, many analysts point to its potential impact on food security, particularly biofuels that are made from agricultural products.

Bioenergy and food security are involved in a complex relationship, and the debate on the subject is essential so that the right decisions are taken to avoid any negative impact on the availability of food in the world. On the other hand, there is no scientific evidence to support the alleged causal relation between bioenergy production and the fluctuation in food prices of recent years.

This paper assesses the debate between those favorable and those opposed to the expansion of bioenergy production in order to understand whether arguments on either side can be detected regularly across different countries. To assess this debate we make a comparative analysis involving several countries undergoing different stages and models of bioenergy production. By comparing the experiences of Brazil, the United States, the European Union, China, India, and South Africa, we sought to observe whether food production has suffered from the recent expansion of croplands that serve as feedstock for biofuels in these countries.

Manuscript received November 25, 2013; revised February 16, 2014.

Paulo C. Manduca, Mauro D. Berni, Rubens Lamparelli, Klaus G. Dalgaard, Luiz A. B. Cortez, and Juan A. Ayarza are with the Interdisciplinary Center for Energy Planning, State University of Campinas (UNICAMP), São Paulo, Brazil (e-mail: manduca@unicamp.br).

\section{The DebATE On BIOENERGY AND FoOd SECURITY}

In a world characterized by complex interdependence and economic and informational globalization, relations between countries are still conducted in a world plagued by poverty and hunger, long before the debate on bioenergy and food security arose. José Graziano da Silva, Director-General of the United Nations Food and Agriculture Organization (FAO), states that there are no absolute truths in the debate on bioenergy, biofuel and food production [1]. The food problem remains a challenge in the 21 st century, regardless of bioenergy production.

FAO estimates that the world produces enough food to feed the entire world population with 3,600 calories per day $(1,200$ calories over what is needed), even though there are around one billion hungry people in the world. Despite being the largest food producers in the world, developing countries are those most plagued by the ills of hunger. Therefore, the problem of hunger is not directly linked to the amount of food produced, but rather to other factors such as the unequal distribution of food. A recent study [1] demonstrates there is no incompatibility between bioenergy production and food security, but there are a number of causes related to economic and financial issues of globalization that perpetuate the world's hunger problem (Shown in Table I).

TABLE I: FACTORS RELATED TO WORLD HUNGER [1]

\begin{tabular}{ll}
\hline \multicolumn{1}{c}{ Factors } & \multicolumn{1}{c}{ Repercussions } \\
\hline Food \& Energy & $\begin{array}{l}\text { Oil and biofuel prices could interact and create } \\
\text { volatility and new tensions. }\end{array}$ \\
\hline Food \& Climate & $\begin{array}{l}\text { Environmental imbalances are direct threats to food } \\
\text { production chains. }\end{array}$ \\
\hline Food \& & $\begin{array}{l}\text { Financial crises and speculation generate increases in } \\
\text { food prices and highlight the sensibilities and } \\
\text { Minancial }\end{array}$ \\
valnets & $\begin{array}{l}\text { The poor are the most affected by the food price crisis, } \\
\text { whose purchasing power is decreased by high prices. }\end{array}$ \\
\hline Indirect Land & $\begin{array}{l}\text { This refers to the fact that, because expanded } \\
\text { agricultural land use in a given country has decreased } \\
\text { the relative availability of land for other crops, } \\
\text { increased bioenergy production would have to come } \\
\text { from farmable land in other regions of the world. The } \\
\text { resulting competition for land in these regions creates } \\
\text { a trade-off between crops grown for food and biofuel } \\
\text { production. }\end{array}$ \\
\hline
\end{tabular}

Particular attention is also deserved to increasing food demand due to changes in the diets of populations worldwide as a result of rising income, especially in emerging countries. With increasing income, meat and dairy consumption also increases, exerting rising pressure on agricultural commodity markets and grain prices, especially those used to produce animal feed. With rising agricultural commodity prices, the competition between food and energy production becomes more obvious. To produce food, intermediate inputs are 
needed in the form of fertilizers and energy conversion, particularly in the transportation sector. The intensity of conventional energy use generates environmental impacts, which are at the center of the international debate on climate change, stimulating demand for clean energy development. This dynamic intensifies the adoption of bioenergy in the global energy mix: in 2008, about $15 \%$ of global corn production (mostly in the US) was used for ethanol production; around $10 \%$ of global vegetable oil production (mostly in the EU) became biodiesel; and $18 \%$ of sugarcane (mostly in Brazil) went to make ethanol fuel [2] (see Fig. 1).

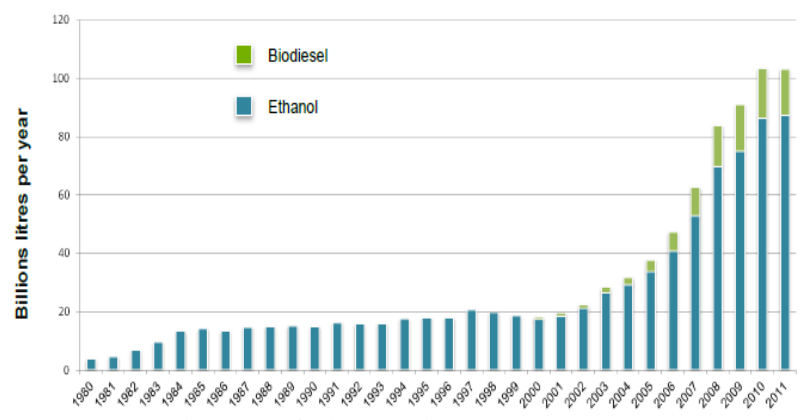

Fig. 1. Biofuel production, 1980-2011 [2].

According FAO [3], however, it is the world's tropical regions that have the best natural conditions for bioenergy production, such as high solar energy incidence, appropriate temperatures, suitable soil and topography, especially between the parallels of latitude $35^{\circ}$ North and $35^{\circ}$ South. In addition to water availability, there is also potential for increasing arable lands in these regions. According to Doornbosch and Steenblik [4], 60\% of the world's potentially available land could be used to produce bioenergy by 2050 (440Mha), of which almost $60 \%$ (250Mha) will be in Latin America and the Caribbean, and most of the remainder in Africa (180Mha). Smeets et al. [5] have also shown that these regions have the greatest potential for energy crop production. Depending on the scenarios proposed by the authors, potential energy production ranges from 90 to $280 \mathrm{EJ} / \mathrm{year}$ in Latin America and the Caribbean, and from 50 to $350 \mathrm{EJ} /$ year in Sub-Saharan Africa.

Bioenergy advocates argue that its production can help small farmers in developing countries to produce their own energy for use in agricultural machinery and electricity co-generation. Farmers can also benefit from better prices for their products. But for this to happen, a solid institutional framework needs to be set up to guide the policies and technologies adopted to ensure the productive system's sustainable development [6]. It is vital that governments implement public policies for integrated resource planning. Such policies must be appropriate to the objectives of minimizing the risks while maximizing the opportunities that bioenergy could play in agriculture, renewable energy and food supply of developing countries in an environmentally and economically sustainable manner.

\section{The MAIN Players IN THE DEBATE ON BIOENERGY AND} FOOD SECURITY

\section{A. Brazil}

The importance of bioenergy in Brazil is the result of a number of factors, including the size of the country and the availability of land, favorable climate, the availability and low cost of labor, and the mastery of technology for sugarcane production and conversion into biofuels and electric power in sugar mills. Sustained energy planning is used to assess the ability of supply to meet demand for both food and energy, in a complementary context for Brazil to leverage its own development, while considering the whole lifecycle of bioenergy production systems. This system includes both the upstream sector-i.e., production inputs (seeds, fertilizers, pesticides, tractors, fuel) - as well as the downstream sectors (labor, production process, transport, sale and finally retail negotiations).

Brazil differs in relation to developing countries suffering the hardships of hunger because it has no shortage of food supplies. The main characteristics that determine the relationship between poverty and hunger in Brazil are the major social disparities and poor spatial distribution of available resources. Brazil's agricultural products that are destined for export come from "agribusiness" and are not part of the food security model that the government intends to implement nationally, which is characterized by a traditional family farming model that encourages small producers to ensure local supply. In the case of biofuels, particularly ethanol, the Brazilian government argues that they hold no threat to food production. The area used for sugarcane production for bioethanol uses merely $0,4 \%$ of Brazil's total area (see Fig. 2).

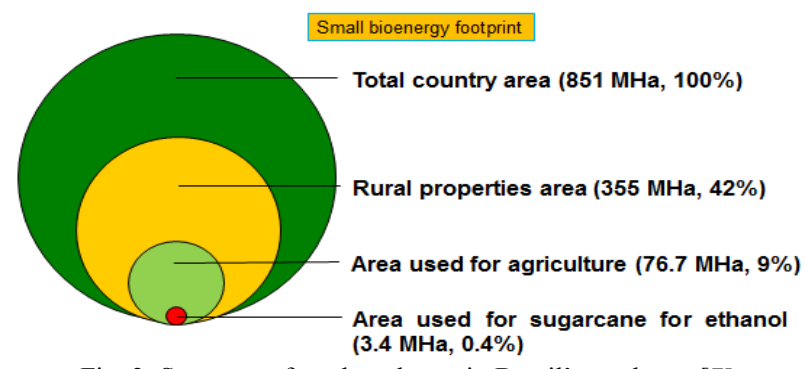

Fig. 2. Sugarcane for ethanol uses in Brazil's total area [7].

Due to Brazil's vast territory and growing concerns about GHG emissions, coupled with the occasional need to import certain petroleum products, bioethanol emerges as a modern alternative energy source that also contributes to rural prosperity while minimizing environmental impacts. Bioethanol is a renewable and sustainable product with the ability to replace a significant portion of global demand for gasoline. A study confirmed Brazil's potential to replace $10 \%$ of global gasoline demand by 2025, using bioethanol from sugarcane [8].

Through its Ministry of External Relations, the Brazilian government has advocated the recognition of the environmental, social and economic benefits of bioenergy, while promoting the necessary conditions a free international market for biofuels. Their greatest objective is to promote the "commoditization" of biofuels [9], [10]. In that sense, Brazil's diplomacy pleas for the end of barriers on agricultural products from developing countries in order to give traction to its food and energy security agenda in different international forums. The argument is that such barriers hinder the consolidation of a framework for food 
security in developing countries, since it prevents them from competing equally in international trade.

\section{B. Colombia}

Colombia, whose production started in late 2005, is the world's second-largest ethanol producer from sugarcane after Brazil. Government regulations established a mandatory blend of E10 with gasoline. Current ethanol production covers $85 \%$ of local needs to comply with the blending mandate. Of the 13 sugar mills in Colombia, 5 of these plants produce all of the current ethanol production, approximately 1.05 million liters per day. Colombia uses Indian technology for vinasse, water and energy use. In 2008, the Colombian government set a policy framework for the biofuels sector that guarantees a minimum price for producers, tax exemptions for feedstock growers, and an overall commitment from the government to support biofuel production and development. As such, Colombia has developed an aggressive biofuels policy based on mandates and it is expected that the domestic market will absorb all its production in the coming years [11]. In Colombia, palm oil is currently seen as the most viable alternative to coca and some accounts suggest that the results are having a positive effect for small producers both in terms of income and in the concomitant opportunity for associated food crop production. Other studies, both with regard to Colombia and other Latin American countries, have identified biofuel expansion with encroachment on peasant lands [12].

\section{The United States}

The first decade of this century saw a dramatic surge in biofuels in the United States, especially following the 2003 Renewable Fuel Standard (RFS) legislation, which called for phasing out Methyl tertiary-butyl ether (MTBE) as a gasoline additive for which ethanol was the only practical substitute. The ban on MTBE created a 3.5 billion gallon (13.2 billion liters) market for ethanol. The 2005 Energy Policy Act required 7.5 billion gallons of ethanol (28.4 billion liters) to be incorporated into transport fuels by 2012, at the same time putting in place a system for trading ethanol credits. Government support for biofuels was also justified in terms of job creation and there was concern for the inclusion of small-scale producers and agricultural cooperatives into the program, in line with dispositions contained in the 2004 American Job Creation Act and the 2005 Energy Policy Act. The new US targets were accompanied by a host of state and federal policy support measures, such as tax incentives, fuel quality regulations, federal or state car fleet requirements, credits for alternative fuel motors, as well as state subsidies to producers, grants and loan programs, and tax exemptions. As a result, ethanol production in the US skyrocketed from 1.7 billion gallons ( 6.4 billion liters) in 2001 to 13.9 billion gallons ( 52.6 billion liters) in 2011, overtaking Brazil, whose ethanol sector only produced 20.8 billion liters in 2011, after the 2008 financial crisis put a hold on new investments, driving up the price of ethanol towards potentially uncompetitive levels with gasoline, whose price was maintained artificially low through government subsidies [2].

\section{The European Union}

Through its European Economic and Social Committee (EESC), the European Union believes that food security must be placed at the center of the region's policies as a precondition for a strategy for global stability. The EESC stresses the need to reduce dependence on imported fossil fuels, without forgetting the security of food supply, the competitiveness of European agriculture and soil degradation, while establishing a direct correlation between food security and bioenergy production. Moreover, given the investments made in recent years, it will eventually be possible to limit the production of biofuels from food crops and to support "advanced" fuels by encouraging the production of second-generation biofuels that use wood and straw as feedstocks. In 2009 the EU recorded a 4.4\% global reduction in energy consumption, including $5 \%$ in the US and $5.5 \%$ in the EU, while non-OECD countries increased their overall energy demand by $2 \%$. In addition, the nuclear disaster at the Fukushima power plant in Japan must also be taken into account, since it led some EU member states, most notably Germany, to abandon nuclear power for energy production [13]. Currently, the whole EU imports $80 \%$ of its oil, $60 \%$ of its natural gas and $40 \%$ of its coal needs to meet its energy demand, estimated at 1583.3 million tons of oil equivalent (Mtoe). Non-renewable energy sources make up $91 \%$ of the EU's energy use $(36.6 \%$ oil, $24.5 \%$ natural gas, $15.7 \%$ coal and $13.6 \%$ nuclear) while renewable sources of energy represent merely 9\% (6.1\% from biomass, biogas and municipal waste, $1.7 \%$ from hydroelectricity, $0.7 \%$ from wind energy, $0.3 \%$ from geothermal and $0.1 \%$ from solar and photovoltaic energy). Thus the EU is increasingly dependent on energy imports. It is estimated that by 2030, the $28 \mathrm{EU}$ member states will import $84 \%$ of their natural gas, $59 \%$ of their coal and $94 \%$ of their oil needs [13]. Based on data from 2009, the EU's transport sector has the highest percentage of energy consumption, around $33 \%$, followed by the residential sector with $26.5 \%$, industry with $24.2 \%$, the services sector with $14 \%$, and finally agriculture with $2.3 \%$ [2].

\section{E. China}

China has sustained three decades of record-high economic growth and has brought some 300 million people above the poverty line. Nevertheless, given the size of its population, it still accounts for $25 \%$ of the world's poor and food insecure [14]. Due to the size of its economy and its high rate of economic growth, GHG emissions are increasing. Its car sales market, 18.5 million in 2011, is now the largest in the world and is expected to increase to 30 million a year by 2020 . Current estimates put China's automobile fleet at over 100 million with a projection of some 200 million vehicles by 2020. China is also dependent on oil imports: they accounted for $55 \%$ of oil needs in 2010, a figure estimated to increase to $75 \%$ by 2030 . China launched its renewable energy policies in 2000 and set a renewable energy target of $10 \%$ of total energy demand by 2010 , increasing to $15 \%$ by 2020 . For liquid biofuels, the target set for 2020 was 10 billion liters of ethanol and 2 billion liters of biodiesel, and five large-scale plants were constructed. According to the High Level Panel of Experts on Food Security and Nutrition [2], such an ethanol target represents $14 \%$ of total gasoline consumption, but would use $20 \%$ of China's maize/corn production, some 32 million tons, and $6.6 \%$ of all its cereal production at 2009 figures. Soil degradation through the use of cropland for 
biofuels was identified as the greatest threat to China's food security.

\section{F. India}

India imported $75 \%$ of its crude oil consumption in 2010. It was the third-largest emitter of $\mathrm{CO}_{2}$ after China and the US in 2009. Its vehicle fleet was 90 million in 2005, increasing to 140 million in 2011. With vigorous economic growth between $6 \%$ and $8 \%$ per year, annual growth of the transport sector is currently around $8-10 \%$ per year. Some $51 \%$ of petroleum consumption goes to transport, against only $4 \%$ for agriculture. Both as a response to dependence on energy imports and to the concern over growing emissions owing to a rapidly increasing transport sector, India has adopted the European Union norms on emissions, which involve the promotion of clean fuels. In 2003, it decided on a $5 \%$ ethanol blending program, but by the end of that decade only a $2 \%$ blend had been achieved and biodiesel was insignificant [15]. India's bioethanol comes mainly from molasses, although favorable harvests may permit the use of sugarcane juice. Imports of biofuels are not permitted, although alcohol is both exported and imported. India's sugarcane harvests are very cyclical, which means that bioethanol supplies are also irregular. In light of good harvests in the middle of the last decade, India increased its target to $5 \%$ and later to $10 \%$, although these figures have not yet been met [2]. Nevertheless, a target for $20 \%$ for all biofuels was set for 2017 in the National Policy on Biofuels in 2009. Although, for many reasons, ethanol has not advanced as planned as a transport fuel, electricity from sugarcane biomass is an important factor in power generation for many plants in the sector and in other industries.

\section{G. Mozambique}

Mozambique has the potential to become one of the major biofuel producers in Africa, and other agribusiness ventures are booming too. The ProCana bioethanol company will process its cane in a Brazilian-built sugar-ethanol factory. It will lay miles of track to link the plant up with the national rail network. Once the operation is up and running, ProCana will raise US\$290 million from hedge funds for a project to plant 20,000 hectares of sugarcane and a bioethanol unit. Last year, the Central African Mining \& Exploration Company invested US\$ 150 million in an ethanol plant, while Petromoc spent US\$ 550 million to develop biofuels. In spite of the impressive economic turnaround achieved over the past few years, Mozambique remains largely a rural country, suffering from widespread poverty, vulnerability to natural disasters and economic shocks, and major socioeconomic imbalances between its rural and urban populations [2].

\section{H. South Africa}

South Africa has focused its biofuels program on "underutilized land" - a concern evident both in India and China - and on small producers marginalized by apartheid, which is similar to Brazil's biodiesel program. The results have so far been very unpromising. One fundamental difference, however, was the exclusion and banning of jatropha as an exotic plant, which it was thought could become invasive in the South African context. The first moves to develop biofuels came from the established sugar and, particularly, maize growers, but these were thwarted by the criteria governing the government's biofuels policy in 2007. It was decided that, for food security reasons, maize should not be acceptable as a feedstock until underutilized land has been fully put into production and measures put in place to guard against extreme food inflation. Sugarcane, sugar beet and soybean projects have been approved but the overriding condition is that feedstocks should be from crops produced in underutilized lands. The program's objectives were neither inspired by dependence on energy imports, nor by concern with $\mathrm{CO}_{2}$ emissions. Here the South African context differs from those of China and India. Where it has closer parallels is in the objectives of using its biofuel program to promote rural development, alleviate poverty and focus on non-cultivated lands, more specifically "new and additional lands" and/or "currently underutilized lands." The initial target was for an overall voluntary $2 \%$ blend, broken down into B2 (2\% biodiesel) and E8, given the overwhelming dominance of diesel-driven vehicles. It was claimed that this would only occupy $1.4 \%$ of croplands and would create over 25,000 jobs. The targeted land was situated in the homelands, where an estimated $14 \%$ of the land was underutilized. A further goal was to focus the program on products that had been grown previously, and on small farmers discriminated by apartheid. In this respect, the program echoes the Brazilian biodiesel program, which has similarly tried to base itself on family farmers, choosing the feedstock in accordance with different regional farming practices [2], [16].

\section{FINAL REMARKS}

In the current literature, the debate between bioenergy production and food security is invariably related to issues of poverty and hunger. The alleged incompatibility of agricultural production for food and biofuel production thus appears to be the sole result of the recent expansion of the agro-industrial sector, especially in developing countries. If so, it would seem accurate to say that food insecurity is a new theme, which is not actually the case.

The issue of food security is not a new one. It should be noted that the expansion of free trade during the eighteenth century led Adam Smith to formalize the academic argument about the gains of trade, while calling for an end to protectionism in general, and for agriculture in particular, when production costs were lower elsewhere.

In the twenty-first century, the coordinator of FAO's Bioenergy Program, Olivier Dubois, has stated that there is a constant need for land mapping to investigate the environmental impact of agricultural production, highlighting the fact the indirect effects of land use need to be investigated to avoid damages made mainly to family farming around the world. In Dubois' assessment, bioenergy and food production are not necessarily incompatible: "We cannot demonize something because a lot depends on how you do it. You cannot compete [food crop] land use with biofuel production, but coexistence is possible. Food crops as raw material can be maintained in a consortium of different crops in the same field" [17].

In response to these issues, the UN-FAO Bioenergy and Food Security Criteria and Indicators (BEFSCI) project aims 
to develop detailed principles, criteria and indicators on sustainable bioenergy production that safeguard food security These indicators include tools to assess the environmental and socioeconomic impacts of bioenergy production, which can be measured during production, and recommend best practices and policies to promote the sustainable development of bioenergy. These tools have helped identify sustainable ways to balance energy and food production - for instance by using crop byproducts to feed cattle, crop rotation or mixing crops [18]. In other words, it is a form of what is called an Integrated Resource Plan (IRP) in sustainable energy planning.

Finally, it is worth noting that besides the implications for food security and agricultural structures, bioenergy can have positive effects in terms of agro-industrial development and job creation. The bioenergy sector's potential to reduce poverty and hunger in the world depends in good part on the correct formulation and implementation of public policies, which according to FAO [19] should consider the following aspects:

1) Development and land use policies, starting with an agro-ecological zoning of land available for bioenergy crops, followed by incentives and penalties for the use of forests, water and other resources;

2) Technology policies that explore all the possible raw materials in a region that are accessible to small farmers and are geared towards small-scale technologies for both the agricultural sector and end-use industries;

3) Regulatory policies for products and services which clearly define the regulatory framework for the use of biofuels markets, trading standards, their incentives and taxes; and

4) Policies to improve the contractual relationships between the various actors in the production chain, from primary production to final consumption, along with the inclusion of family agriculture and the guarantee of labor rights.

\section{REFERENCES}

[1] P. F. Brasil, "O Brasil e a insegurança alimentar global: forças sociais e política externa (2003-2010),” M.A. thesis, Institute of International Relations, University of Brasília, Brasília, 2013.

[2] Biofuels and Food Security, High Level Panel of Experts on Food Security and Nutrition of the Committee on World Food Security, 2013.

[3] Climdata Rainfall Database, Food and Agriculture Organization (FAO), 1997

[4] R. Doornbosch and R. Steenblik, "OECD roundtable on sustainable development, biofuels: is the cure worse than the disease?" $O E C D$, 2007.

[5] E. M. Smeets et al., "Bottom-up methodologies for assessing technical and economic bioenergy production potential," in Agriculture and climate beyond 2015: A New Perspective on Future Land Use Patterns, Environment and Policy, F. Brouwer and B. A. McCarl, Ed. Netherlands: Springer, 2006, ch. 9, pp. 147-170.
[6] Food and Agriculture Organization (FAO). Press release: terceiro comunicado de imprensa - cúpula de ministros e biocombustíveis. (March 19, 2008). [Online]. Available: https://www.fao.org.br/cr_imprensa3.asp

[7] Bioetanol De Cana-De-Açúcar - Energia Para O Desenvolvimento Sustentável, Banco Nacional de Desenvolvimento Econômico e Social (BNDES) and Centro de Gestão e Estudos Estratégicos (CGEE), 2008.

[8] Bioetanol Combustível: Uma Oportunidade Para O Brasil, Centro de Gestão e Estudos Estratégicos (CGEE), Brasília, 2009.

[9] K. G. Dalgaard, "The energy statecraft of Brazil: promoting biofuels as an instrument of Brazilian foreign policy, 2003-2010," Ph.D. dissertation, Department of International Relations, The London School of Economics and Political Science, 2012.

[10] M. A. Vieira and K. G. Dalgaard, "The energy-security-climate-change nexus in Brazil," Environmental Politics, vol. 22, no. 4, pp. 610-626, July-Aug. 2013.

[11] US Department of Agriculture Global Agricultural Information Network (July 2013), Colombia Biofuels Annual 2013. [Online]. Available:

http://gain.fas.usda.gov/Recent\%20GAIN\%20Publications/Biofuels\% 20Annual_Bogota_Colombia_6-28-2013.pdf

[12] S. M. Borras et al., "Land grabbing in Latin America and the Caribbean," Journal of Peasant Studies, vol. 39, no. 3-4, pp. 845-872, July-Oct, 2012.

[13] European Economic and Social Committee. Opinion of the section for agriculture, rural development and the environment on food security and bioenergy. (September 18, 2013). [Online]. Available: http://www.eesc.europa.eu/?i=portal.en.nat-opinions. 29042

[14] A. Sumner, "Where do the poor live?" World Development, vol. 40, no. 5, pp. 865-877, 2012.

[15] US Department of Agriculture Global Agricultural Information Network. India biofuels annual 2012. (June 2012). [Online]. Available: http://gain.fas.usda.gov/Recent\%20GAIN\%20Publications/Biofuels\% 20Annual_New\%20Delhi_India_6-20-2012.pdf

[16] T. Funke et al., "Modeling the impacts of the industrial biofuels strategy on the South African agricultural and biofuels subsectors," Agrekon, vol. 48, no. 3, pp. 223-244, Sep 2009.

[17] A. Brasil. FAO: progresso da bioenergia não pode afetar segurança alimentar. (March 23, 2013). [Online]. Available: http://agenciabrasil.ebc.com.br/noticia/2013-03-23/fao-progresso-dabioenergia-nao-pode-afetar-seguranca-alimentar

[18] Food and Agriculture Organization (FAO), BEFSCI project: an overview. (2010). [Online]. Available: http://www.fao.org/bioenergy/23448-096924bc1fdef98a9eeb46c76eff 6d83b.pdf

[19] Food and Agriculture Organization (FAO), The state of food insecurity in the world: how does international price volatility affect domestic economies and food security? (2011). [Online]. Available: http://www.fao.org/docrep/014/i2330e/i2330e.pdf

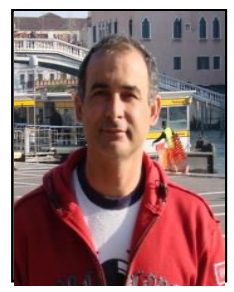

Paulo Cesar Manduca received his $\mathrm{PhD}$ in sociology on international affairs from University of São Paulo USP (Brazil) in 2002 and his MSc degree in political science from University of Campinas - UNICAMP (Brazil) in 1995. Since 1997 he is a researcher at UNICAMP firstly at the Center for Strategic Studies and after 2010, at the Interdisciplinary Center for Energy Planning of UNICAMP. In 2002 he became a senior professor at UNIP - Universidade Paulista - and in 2009 became a member of the Political Science Department of UNICAMP. Now, he is engaged on Bioenergy Contribution of Latin America, Caribean and Africa to the GSB (Global Sustainable Bioenergy) Project - LACAf-Cane-I - project which is supported by São Paulo Research Foundation-FAPESP. 
Hydrogen Energy 
